\title{
New Product Pricing Strategy and Product Performance Assessment in Fast Moving Consumer Goods
}

\author{
Submitted 29/07/19, $1^{\text {st }}$ revision 11/09/19, $2^{\text {nd }}$ revision 21/10/19 accepted 22/1 1/19
}

\author{
R. Agus Trihatmoko ${ }^{1}$, Dian Indri Purnamasari ${ }^{2}$
}

\begin{abstract}
:
Purpose: This article combines the two perspectives of management interests, namely marketing and finance regarding Fast Moving Consumer Goods (FMCG). The aim is to uncover the marketing environment on pricing strategies in a competitive market environment, product and financial performance as well as assessing product success based on price strategies.

Design/methodology/approach: Qualitative research methods are used by the design of a combination of grounded theory and phenomenology, as well as constructive approaches.

Findings: The results identify that the marketing environment in terms of price is a consideration of buyer' decisions and is related to the product marketing environment, and the environment of market competition, namely price activities, antecedents and price outcomes. The marketing environment of price is created based on the marketing environment of product and consumer market competition, while the product performance is determined by the environment of business and consumer market competition. These findings contribute to the conception of business buyer behavior and the marketing mix.

Practical implications: The results implications refer to the practice of corporate management on financial management of working capital, and marketing management in general.

Originality/value: The originality of this paper comes from the exploration of pricing strategies in an effort to determine the relevance between product performance and finance, and the success of new "FMCG" products.
\end{abstract}

Keywords: Pricing strategy, new product, marketing mix, business buyer behavior, fast moving consumer goods (FMCG), financial performance.

JEL code: $G 34$.

Paper type: Research article.

\footnotetext{
${ }^{1}$ Faculty of Economics and Graduate Study Program, Universitas Surakarta, Surakarta, Indonesia, email: agustricentre@gmail.com

${ }^{2}$ Faculty of Economics and Business, Universitas Pembangunan Nasional Veteran, Yogyakarta, Indonesia.
} 


\section{Introduction}

The price level disparity for mass products such as Fast Moving Consumer Goods (FMCG) is relatively different comparing to competing products in the market (Trihatmoko, 2016). This phenomenon indicates that the determination of the pricing strategy of a new product requires accuracy and must be done with consideration by marketers. The price level of new products should be cheaper compared to the prices of the established competitor's products, as the first ones can't be imediatly positioned at a compareble level on the market. One of the price related objectives is to set a market position or get a product market share among the competing products in the market (Cravens et al., 2009). The research results of Ailawadi, Lehman, and Neslin (2001) state that net prices have an impact on market share, however, overall the model share of a product is also influenced by the competitor's marketing mix strategy factors of the concerned product. Exploring the concept of marketing mix includes the exploration each of the structures, namely product, distribution, promotion and price (4P's) and it is a complex work (Trihatmoko and Mulyani, 2018).

New products competing in the FMCG market are a strategic outcome of manufacturers in terms of brand strategies (Nijssen and Agustin, 2005; Trihatmoko, 2016; Trihatmoko et al., 2018). The new product strategy should be integrated according to the 4P's strategies, so the pricing strategy set by the company is part of corporate management, and in this case, it is also related to the relationship marketing, which represents the connection to the customers. A broader approach of the subject shows that it is a strategic position that will be considered to be an option for organizations to maintain their competitive advantage (Hansen and Mowen, 2005) based on specific strategies.

The first strategy, named cost leadership, refers to the products or/and services choice, that should prioritize the cost efficiency and an output homogeneity. This is still an option for many organizations whose processes and output are the same, for which the cost efficiency is a priority. The second strategy, the differentiation, refers to a choice of products or/and services that represent heterogeneous inputs, processes, and outputs, meaning that their values are not the same or that they have a limited output. This is an option for organizations with strategies that do not discuss much about cost efficiency and have clearly segmented consumers. The third strategy, the value chain, is a choice of strategies for organizations to manage all resources from inputs (availability of raw materials) through processes (manufacturing products or services), and to outputs (in the form of products, to marketing chain processes to consumers) or from upstream to downstream. This strategy was chosen in general to maintain the quality of products and services for consumers and for cost efficiency.

FMCG business problems are indicated to be inseparable from the role of distributors, namely distribution and wholesale companies, or retailers. On the other 
hand, business of wholesalers are products that compete with other product's category from their suppliers (Trihatmoko et al., 2018). The next question is what is the product pricing strategy set by marketers, and how to assess the success of the product. For this reason, the purpose of this study is to reveal the performance of a product and the company's finances, as well as the opportunity for success due to the price strategy set by the company.

\section{Environmental Analysis of Price by the Buyer}

The results of Trihatmoko's (2016) study have identified the essence of buyers' responses into environmental groups. According to the phenomenon of buyer decisions,the purchasing decisions is based on the stimulus of the marketing environment regarding price and product factors and the competitive environment (Pickett-Baker and Ozaki, 2008; Alba et al., 1997). The competitive environment is an antecedent factor and a result of the marketing environment (Jaworski and Kohli, 1993). Constructive analysis identifies grouping of competitive environments, namely competition activities and pricing strategies - outcomes and antecedents.

Figure 1. Analysis of market environment of price in the business buyer behavior

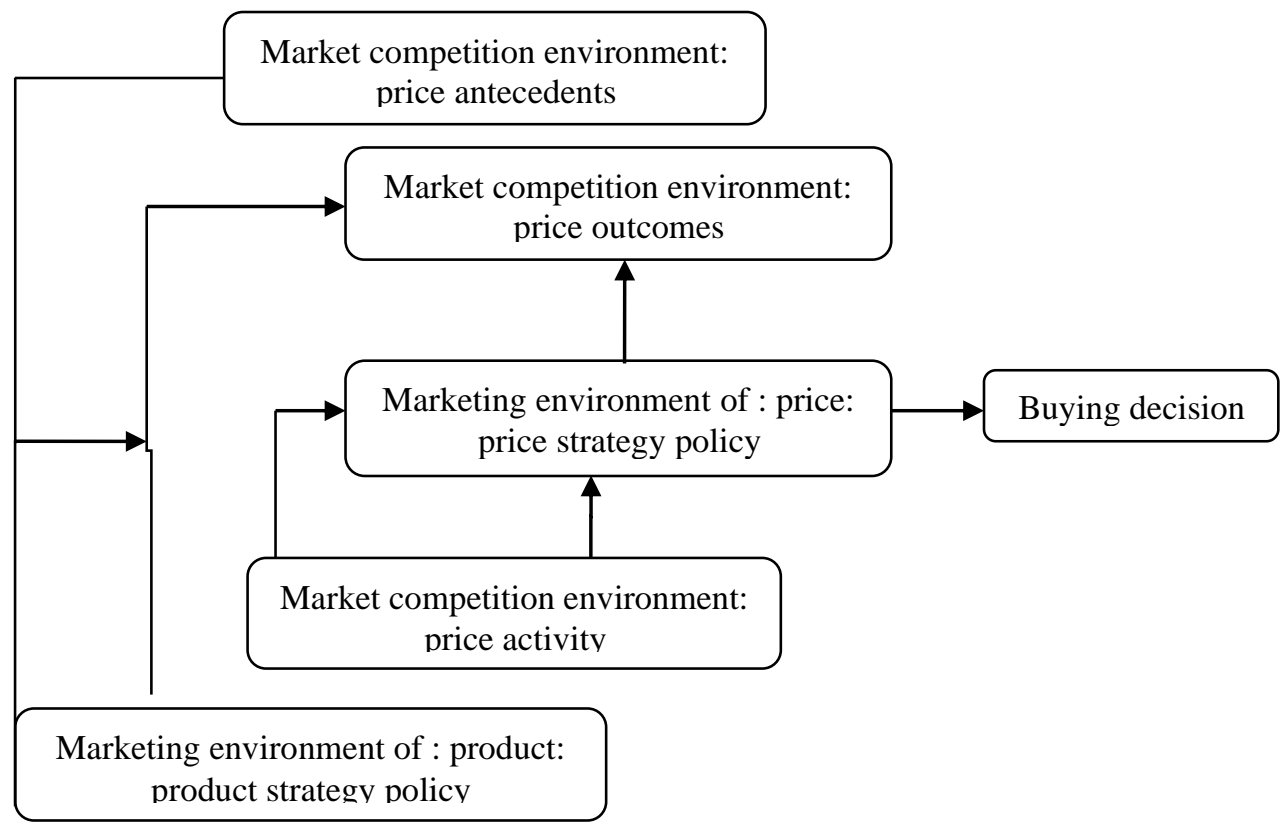

Product displays are wholesale activities in collaboration with suppliers so that new products are easily recognized by wholesale store customers (Sheu et al., 2006; Inman et al., 2009). All products traded by wholesalers compete with each other to be positioned on the display space in the store that is seen strategically by the eyes. The product segment, as well as the demand for competing and categorical products, 
is the market competition - the antecedent of the price strategy. The price marketing is included in the pricing strategy, namely the price level, terms of payment (TOP), warranty, return and price structure. The products' marketing environment consists of the product strategy, namely quality, features and product design.

The findings and descriptions above, reconstruct the minor conception of the price's marketing environment analysis by the buyer and becomes the major proposition in this study. Furthermore, it is constructively arranged in accodance to the behavior of purchasing new products with business market purchasing decision process by buyers in the business market (Figure 1).

P1: Prices are determined based on the marketing environment of the product.

P2: Market competition environment (antecendents) is determined based on marketing environment of prices.

P3: Prices determine purchasing decisions.

P4: Prices create a competitive environment of activities.

P5: Prices and price activities have an impact on market competition environment.

\section{Price Strategy and Product Performance}

The buyer's evaluation of the price is based on the prices of the competing products and on the product segmentation (Hausman et al., 2009; Zeithaml, 1988). Likewise, the marketers said that in order to determine the pricing strategy of new products, the price of the competing products and of similar products should be considered as one product category, as well as its segmentation. The determination of pricing strategies takes into considers also other product strategy factors, namely, quality, features and product design (Stremersch and Tellis, 2002; Butscher and Laker, 2000). This finding is helping the buyer to evaluate the price level based on the physical perspective of the product.

Figure 2. Product performance based on pricing strategies in market competition

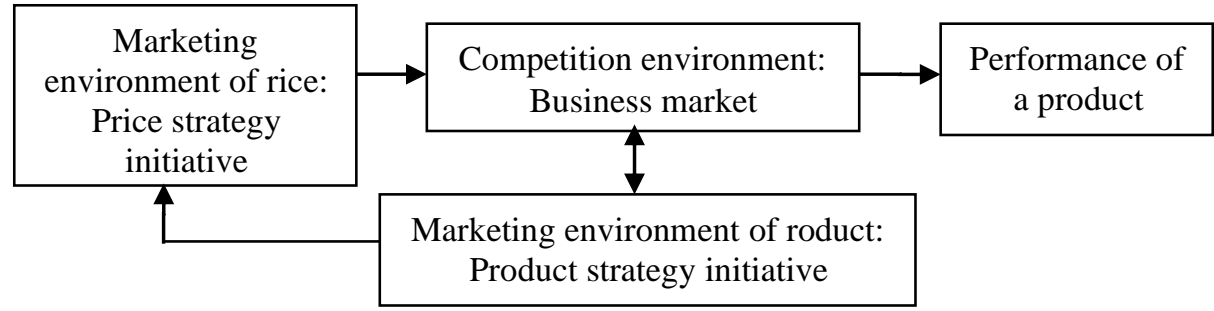

After exploring the buyer's responses, the results indicate that the price aspects are considered by the buyer as "the possibility of buying or rejecting". These findings prove that the decision a customer takes to buy or to reject a new product is a performance when entering the market competition, namely the business market. "If many customers buy products, then product performance can increase. Conversely, if the product of many customers does not buy the product, then the performance of 
the product in the market is not created or slow (the product does not spread in stores)". For this reason, the first time a product can be rated as "good or bad" is identified from the ability of the product to compete in at the customer level.

The textual description explains the phenomenon of new products in entering a market competition. Analyzing the point of view of marketers and buyer, assessing a product strategy in perspective, shows that there is no difference in perception between them. That is, the buyer's abstraction in the form of product valuation from the perspective of price strategies for marketers (Zeithaml, 1988; Stremersch and Tellis, 2002). Price strategies are compiled and implemented in the market competition referring to price competition at the consumer level and the product strategy itself. Products are executed to the market through the company's customers. Price competition in customers (shops) is valued based on price competition at the consumer level and segmentation. Market competition at the consumer level tightens product competition at the store level (Figure 2).

P1: Product pricing strategy initiative is considering the competition environment of the consumers.

P2: Product pricing strategy initiatives refer to the marketing environment of products to product strategy initiatives.

P3: Company pricing in initiating price strategies has an impact on business market competition.

P4: The environment of business market competition has an impact on the competitive environment of the consumer market.

P5: The environment of consumers' market competition influences the environment of business market competition.

P6: Business market competition environment and consumers determine the performance of a product.

Product displays are the efforts marketers take, to improve the image and the reliability of brands of products to consumers. Brand image and the reliability of products are expected to create product demand (Figure 3).

P1: Product displays by the flexible factor of customer payment terms enhance the image and reliability of product brands on the market.

P2: Products that are built through a price strategy drive product demand in the market.

Identifying the variables in this concept also resulted that the product strategies are used as a product performance gauge, namely product display action, image value and brand reliability of the product, product demand level, and sales turnover. These indicators mark opportunities for the success of a new product. 
Figure 3. Product performance flow based on pricing strategies in market competition (red box is the main considerations)

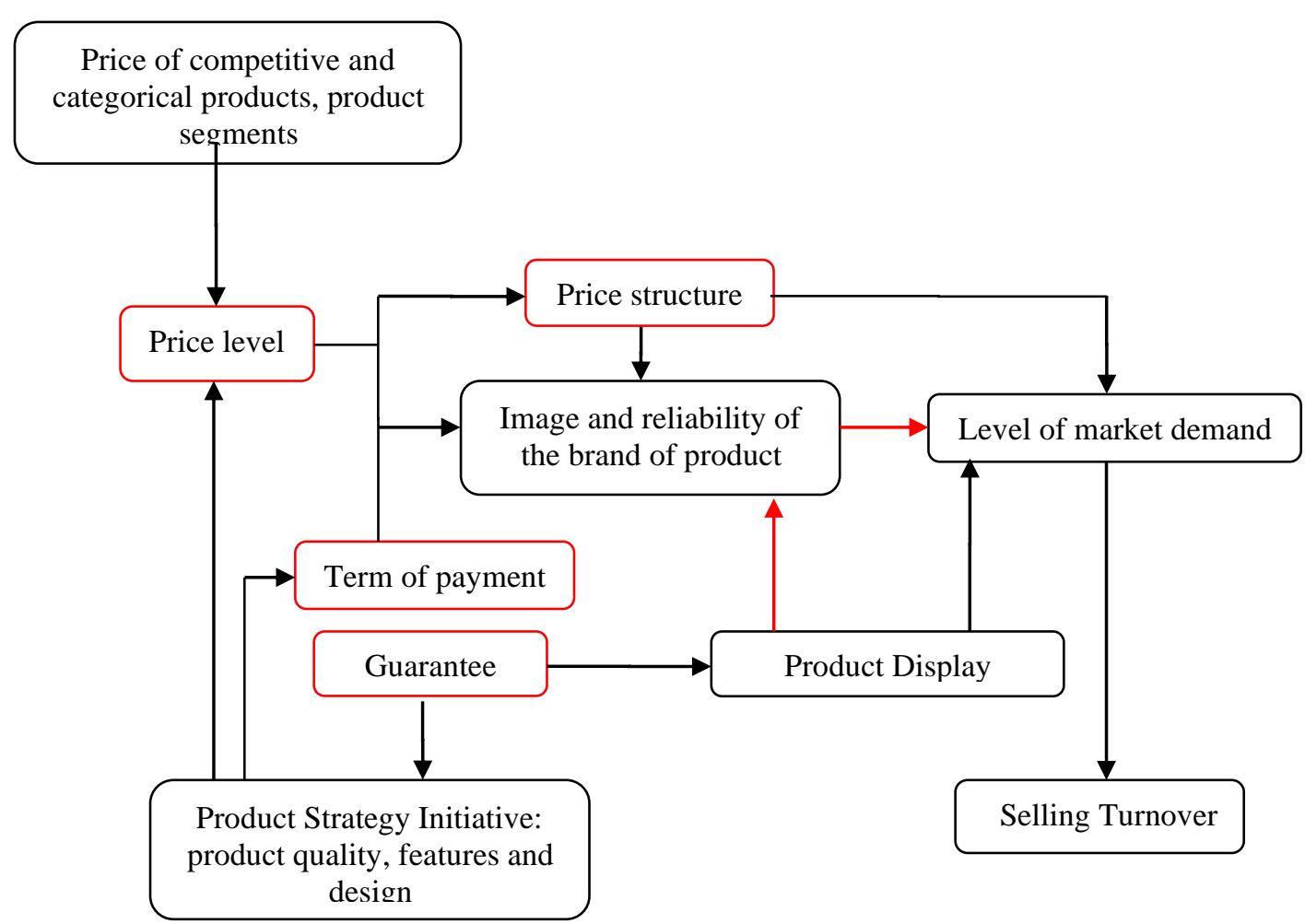

\section{Conclusions}

The exploratory results of purchasing behavior in the business market (wholesaler) regarding the marketing environment of price, give a conclusion that buyer consider their decisions based on the marketing factors of price, namely the price level, terms of payment, product return guarantee and price structure. The buyer assessing the marketing environment of price refers to the marketing environment of the product about quality, features and product design, as well as the market competition environment about the prices of competing products and product category and product segmentation. The buyer's argument against the consideration and evaluation of the marketing environment of price, product and market competition to expect product performance capabilities is entering the market competition environment from the results of the strategy and activity of the price strategy itself.

For this reason, it is recommended to marketers (manufacturing companies), in the preparation of a new product pricing strategy, to compare the price level with competing products in a category of "similar" products. Moreover, it can be done by assessing the suitability of the price level with the consumer's purchasing power in 
the segment. In this case, in the traditional market for the lower middle class, while assessing the advantages or usefulness of the physical product unit against the set price level and comparing with competing products. It is needed to regulate direct marketers (distributor or salesperson companies) with specific regulations regarding customer payment term and return guarantee for new products.

\section{References:}

Alba, J., Lynch, J., Weitz, B., Janiszewski, C., Lutz, R., Sawyer, A. and Wood, S. 1997. Interactive home shopping: consumer, retailer, and manufacturer incentives to participate in electronic marketplaces. Journal of marketing, 61(3), 38-53.

Butscher, S.A. and Laker, M. 2000. Market-driven product development. Marketing management, 9(2), 48.

Cravens, D.W., Piercy, N.F. and Baldauf, A. 2009. Management framework guiding strategic thinking in rapidly changing markets. Journal of Marketing Management, 25(1-2), 31-49.

Hansen, D.R. and Mowen, M.M. 2005. Environmental cost management. Management accounting, 7, 490-526.

Hausman, J., Leonard, G. and Zona, J.D. 1994. Competitive analysis with differenciated products. Annales d' Economie et de Statistique, 159-180.

Inman, J.J., Winer, R.S. and Ferraro, R. 2009. The interplay among category characteristics, customer characteristics, and customer activities on in-store decision making. Journal of Marketing, 73(5), 19-29.

Jaworski, B.J. and Kohli, A.K. 1993. Market orientation: antecedents and consequences. Journal of marketing, 57(3), 53-70.

Nijssen, E.J. and Agustin, C. 2005. Brand extensions: A manager's perspective. Journal of Brand Management, 13(1), 33-49.

Pickett-Baker, J. and Ozaki, R. 2008. Pro-environmental products: marketing influence on consumer purchase decision. Journal of consumer marketing, 25(5), 281-293.

Sheu, C., Yen, H.R. and Chae, B. 2006. Determinants of supplier-retailer collaboration: Evidence from an international study. International Journal of Operations \& Production Management, 26(1), 24-49.

Stremersch, S. and Tellis, G.J. 2002. Strategic bundling of products and prices: A new synthesis for marketing. Journal of Marketing, 66(1), 55-72.

Trihatmoko, R.A. 2018. An Assessment of the Demand for New Products of Fast Moving Consumer Goods (FMCG). Doctoral dissertation, Universitas Slamet Riyadi.

Trihatmoko, R.A., Mulyani, R. \& Lukviarman, N. 2017. Product Placement Strategy in the Business Market Competition: Studies of Fast Moving Consumer Goods.

Trihatmoko, R., Harsono, M., Wahyuni, S. \& Haryono, T. 2016. Buyer-seller relationship constructions in the business buyer behavior: wholesaler and distributor fast moving consumer goods (FMCG) industry in Indonesian market place. Clear International Journal of Research in Commerce \& Management, 7(5).

Zeithaml, V.A. 1988. Consumer perceptions of price, quality and value: a means-end model and synthesis of evidence. Journal of marketing, 52(3), 2-22. 